Social Work/Maatskaplike Werk Vol 56 No 2; Issue 1

http://socialwork.journals.ac.za/pub doi:http://dx.doi.org/10.15270/56-2-815

THE DILEMMA FACED BY NPOS IN RETAINING SOCIAL WORKERS: A CALL TO REVISIT THE RETENTION STRATEGY

Rebecca M Skhosana

The high turnover of social workers in the non-profit organisations (NPOs) sector in South Africa is a major problem that requires further investigation despite the number of studies that have already been conducted in this area. This qualitative study seeks to contribute to the retention of social workers in the NPO sector, and is based on an exploratory survey of the various factors that lead to high social worker turnover. The findings of this paper confirm that NPOs are faced with several challenges in relation to the retention of social workers, and this calls for revisiting the existing retention strategy.

Ms Rebecca M Skhosana, Lecturer, Department of Social Work, University of South Africa, Pretoria, South Africa.

skhosrm@unisa.ac.za 


\section{THE DILEMMA FACED BY NPOS IN RETAINING SOCIAL WORKERS: A CALL TO REVISIT THE RETENTION STRATEGY}

\section{INTRODUCTION}

The high turnover of social workers remains one of the persistent problems faced by the NPO sector. According to Budlender and Proudlock (2011) and Lombard (2008), organisations are facing significant difficulties regarding the drastic shortage of social workers, which makes it costly for them to deliver efficient social services. Budlender and Proudlock (2011) called it a crisis, since the social work profession has been declared a scarce skill by government. A study by Curtis, Moriarty and Netten (2009) reports that the present crisis is so severe that social work is now on the national occupational shortage list. The critical question to be answered is the following: Is social work a scarce skill or is there simply a shortage of organisations to employ social workers or is the budget lacking to sustain the profession?

In South Africa a major study was commissioned by the Department of Labour that explored social work as a scarce and critical skill (Earle, 2008a). The South African Council for Social Services Professions (SACSSP) reported that the Council has registered 60000 social service professionals in South Africa. There are 48000 fully qualified social service professionals, about 31000 social workers, and about 10000 child and youth care workers. The number of students registered as social workers and child and youth care workers amounts to approximately 19000 (Mabetoa, 2018). This statistic is a matter of concern in the light of the ever-increasing social challenges faced by individuals, families and communities in South Africa as well as the high turnover rate of social workers. Jacobs (2012) and Patel (2010) emphasised that the failure to retain experienced social workers has a serious impact on the functioning of organisations, which in turn contributes to a lower standard in the quality of services provided. The shortage of social workers in rendering social services is hampering the ability of organisations to meet the increasing demands for social services.

This shortage of social workers further exposes South African's most vulnerable groups to a greater risk of harm. According to the report by the Department of Social Development (2009a), the shortage of social workers further contributes to a lack of capacity to implement policies and programmes that deal with social issues such as substance abuse, HIV and AIDS, chronic poverty, food insecurity, and other related social conditions. Losing employees is costly to the organisations rendering social services to children living on and off the streets as new employees need to be recruited and trained to acquire the required skills, while former employees take their knowledge and skills with them and children living on and off the streets are left to fend for themselves during the recruitment and training process (Lombard, 2008).

According to Schudrich, Auerbach, Liu, Fernandes, McGowan and Claiborne (2013), much previous research focused on the factors that lead to employees' intention to leave, while less attention has been given to the reasons for the high staff turnover in organisations. Many of the studies identified an employee's intention to stay or leave as a forecast of actual retention or turnover (Anderson, 2000; Ellett, 2009; Landsman, 2001; Schudrich et al., 2013). There is a need to conduct further research in this field as it adds to the expanding body of research on challenges that organisations face in recruiting and retaining social workers. Furthermore, this investigation seeks to contribute to the retention of social workers in the NPO sector. The new knowledge obtained through this study can assist the state in developing strategies that would focus on the retention of social workers in the NPO sector, thereby ensuring the sustainability of organisations that may be on the brink of closing down.

In order to develop a clear understanding of the high turnover phenomenon, a review of the relevant literature was conducted. Lombard (2007) and Streak and Poggenpoel (2005) explain that organisations are the main sources of social services delivery as interventions to help people deal with social 
problems arising from social, economic or political changes. In order to deliver effective services and to receive subsidies, NPOs have to register with the government. According to Littell and Shlonsky (2010) as well as Patel and Hochfeld (2012), the type of social services delivered by an organisation in South Africa is stipulated in the Constitution of the Republic of South Africa (Act, 108 of 1996) and they are shaped by local values, beliefs of the community, the best interest of the child, and available resources. Social services are designed to ensure the safety of children. The primary responsibility for delivering social services rests with the national, provincial and local governments and mostly with organisations (Streak \& Poggenpoel, 2005; Streak, Dawes, Ewing, Levine, Rama \& Alexander, 2008).

Evident in the Department of Social Development Annual Report (2010) and according to Patel and Hochfeld (2012), the contexts within which organisations function have changed as a result of changes in the socioeconomic, political, legislative and policy environments which render open and fair social services to the marginalised and most vulnerable people of society. Patel (2005) and Sanchez (2010) maintain that in rendering social services, organisations should focus on the total population of a specific community or on specific target groups within the community. Social services should further address all the needs in the community or in a specific focus area. Ward and Seager (2010) stipulate that organisations employ a wide variety of programmes to address the needs and rights of vulnerable or disadvantaged groups, such as advocacy and preventive and institutional measures. The specific description of the community, target group and focus area will determine which stakeholders will be involved in service delivery. The focus of this study is on organisations rendering social services to vulnerable groups.

According to Budlender, Williams, Saal, Sineke and Proudlock (2011); Giese (2008); and Skhosana (2013), organisations rely on government funding and their own fundraising efforts to render services and pay their employees. De Sas Kropiwnicki (2010) and Martin (2010) report that financial constraints lead to organisations operating on a smaller scale and are sometimes forced to retrench employees as they cannot afford to pay salaries or stipends to social workers. Budget cuts mean that these organisations are only able to offer few services. This ultimately leads to a reduced level of services and to the retrenchment of social workers. De Sas Kropiwnicki (2010) cautions that this financial implication means that organisations that are known to be champions in rendering social services in particular are underfunded and consequently the quality of early intervention and prevention programmes, and the social services they offer, become limited and undermined.

According to a report by the Department of Social Development's Retention and Recruitment Strategy for Social Workers (Department of Social Development, 2009a), the number of available social workers in the country is insufficient to deal with the demand for social services. The Department of Social Development (2009a) further reports that the shortage of social workers contributes to a lack of capacity to implement policies and programmes that deal with social issues such as substance abuse, HIV and AIDS, chronic poverty, food insecurity, and other related social conditions. According to the Recruitment and Retention Strategy for Social Workers (Department of Social Development, 2009a), this lack of capacity is the result of critical problems in the recruitment of social workers and the fact that recruited social workers cannot be retained by organisations. The Department of Social Development is involved in a recruitment drive to attract more qualified people to the social work profession. However, there is still a gap between the need for and the supply of such workers, since many qualified social workers are unemployed.

The retention of social workers is challenging not only for South Africa, but also for many other countries as described in studies conducted in Australia, the United Kingdom, Ireland, Sweden and the United States of America (Cauvain, 2010; Vermeulen, 2008). The high turnover of social workers is a dilemma that is affecting the NPO sector and has negative consequences for some organisations. According to Armstrong (2006) as well as Robbins and Judge (2011), employee turnover can be described as the rate at which employees enter and leave a company in a given fiscal year. The authors further state that high staff turnover can also take place within the organisation when employees are moved between departments, units or sections, or they are promoted, demoted or transferred. This also 
applies to the organisations working with children living on and off the streets. Du Plooy and Roodt (2010) add that employee turnover rates can increase for a variety of reasons, including employees who resign as well as those who are asked to leave. A survey by Barberton (2006) highlights that a quarter of organisations have experienced a staff turnover of $50 \%$ over a period of six months as a result of frustration, lack of job satisfaction or low salaries.

The research by Lashley (2000) and Nel, Werner, Haasbroek, Poisat, Sono and Schultz (2008) on why people stay or leave organisations found that employees feel compelled by pull or push factors to leave an organisation. The authors differentiate push factors as those within an organisation that cause employees to leave from pull factors which are outside the organisation that influence employees to leave. Abbasi and Hollman (2000) highlight that pull factors draw employees towards other organisations because of higher salaries or benefits. Because of the lower salaries received by social workers rendering social services to children living on and off the streets, social workers are at times lured away from organisations to government sectors by higher pay, better benefits and better job growth opportunities (Skhosana, 2013). Push factors cause employees to look for other jobs as a result of their dissatisfaction with their working conditions. It can be deduced that while pull factors relate to organisational factors that contribute to a high staff turnover, push factors relate to personal reasons that lead to a high staff turnover. These personal factors can have high direct and significant costs for an NPO such as staff replacement and the low morale of the remaining employees, while organisational factors lead to indirect costs such as a disruption in service delivery, and the costs of recruiting and appointing new employees.

\section{RESEARCH METHODOLOGY}

A qualitative research methodology (Creswell, 2014) was adopted in this study to explore and describe the dilemma faced by organisations in retaining social workers. The researcher chose a qualitative design as opposed to other research designs because it allowed flexibility and enabled the research procedure to progress as more observations were collected. Qualitative research methods are appropriate for studies exploring phenomena about which little is known (Rubin \& Babbie, 2013). Within the qualitative research methodology employed, a descriptive and explorative design was applied to understand the factors leading to the high turnover of social workers, and to ascertain how retention strategies can be enhanced from the perspective of social workers employed by organisations in Pretoria, South Africa.

This is a systematic approach in which the observer describes life experiences and situations, and gives them meaning through a series of field notes, interviews and conversations (Burns \& Grove, 2010; Creswell \& Plano Clark, 2011). This approach was appropriate for this study because a holistic understanding of the nature of the high social worker turnover within the NPO sector was sought. The main objective was to gain an in-depth understanding of the factors that lead to high social worker turnover in the NPO sector, and to ascertain how retention can be enhanced.

\section{Population and sampling}

Because the study was qualitative in nature, the population for the study consisted of all social workers in NPOs in Pretoria. In this study the participants were recruited using a non-probability, snowball and purposive sampling method (Creswell, 2014). The sample was selected based on the researcher's existing knowledge of the population, and snowballed for the inclusion of more participants. The researcher noted that there was some difficulty in contacting the initial sample group as some of the organisations had closed down and their contact details no longer existed or functioned.

The participants of the study included three social workers who had resigned but were still serving their notice, and five social workers who were still working at organisations at the time of the survey. The purpose for choosing both groups of participants who are leaving and those who are staying is to understand the factors leading to staff turnover from the two viewpoints. It is worth noting that social workers are not the only group in an organisation experiencing this type of turnover, but that other 
employees such as psychologists, doctors, child and youth care workers, social auxiliary workers, community development workers, administration personnel, house mothers and volunteers are also affected. However, for the purpose of this study, the criterion for inclusion was all social workers employed by organisations in Pretoria. Of the 10 organisations contacted, only six were accessible. Two additional organisations were identified through the snowball technique. A total of eight NPOs were purposively selected as the sample for participation in the study.

\section{Data collection}

Semi-structured interviews, which were guided by a set of predetermined questions from the interview guide, were conducted. Semi-structured interviews allowed the researcher to gain insight into the perceptions, beliefs and experiences of the research participants relating to the research topic. The organisations were contacted and appointments were scheduled. The researcher found it difficult to conduct the interviews as scheduled, since most of the participants had other commitments and had to reschedule their meetings. There were continuous disruptions during the interviews because some organisation had a shortage of staff members; therefore, many of the participants had to attend to their duties while being interviewed. The field notes, interview records and audio tapes were stored in a locked safe to ensure confidentiality.

\section{Data analysis}

To analyse the collected data, the researcher followed the eight steps as proposed by Tesch (cited in Creswell, 2009). These proposed steps entail focusing on making sense of the meaning of data, determining patterns or themes, coding the data, and categorising the data. Because of the need to protect the participants' privacy and anonymity, as well as to be able to thoroughly understand the transcripts in order to obtain a complete view of what occurred during interviews, no independent transcriber was used.

The tape-recorded interviews were listened to and transcribed in Setswana and isiZulu and then translated into English by the researcher. An independent coder was appointed to study the transcripts and identify the major themes and subthemes that became apparent during the interviews. The researcher used Guba's model of trustworthiness of qualitative data as outlined by Krefting (1991) to verify the data. After the data had been analysed, the researcher, supervisor, co-supervisor and the independent coder discussed the results. The exercise provided an opportunity to further probe the results so that the trustworthiness of the data could be established.

\section{Ethical considerations}

Permission to conduct the study was obtained from the Research and Ethics Departmental Committee of the University of South Africa after submitting the research proposal. The researcher also obtained the informed and voluntary consent of all participants before involving them in the study. The researcher explained the purpose and significance of the study to the participants. The participants were notified through email and invited to participate in the study. The participants were provided with sufficient information about the study to allow them to decide for or against participating. Regarding the ethical issues, the participants were assured of confidentiality and presented with consent forms asking them for permission to include them in the study. Once the participants had received all the information about the proposed study, queries were dealt with and they were requested to sign a consent form indicating their willingness to participate in the study.

\section{RESEARCH FINDINGS}

Of the 10 organisations selected, eight employed social workers, while two did not have social workers. The two organisations without social workers were excluded, as they did not meet the criteria for selection. The study indicated that employees at the eight participating organisation included managers, senior social workers and social workers. The age of participants ranged from 28 to 42 years. In terms of their level of education, eight of the participants held a Bachelor's degree. The participants' work experience ranged from six months to five years. One participant had served for five years; three 
participants had served for two years, and three participants for one year. One of the participants in the study had 10 years' experience in the field of social work. In this regard, the participant's broader knowledge and experience in rendering social services within the NPO sector added value to the credibility of the findings of the study by presenting a longer-term picture of the phenomenon under study.

From the data analysis, four broad themes and subthemes were identified that impacted the ability of organisations to retain their social workers. Strolin, McCarthey and Caringi (2007) categorise the causes for turnover according to three factors: individual, supervisory and organisational. From the participants' responses to the challenges faced by organisations in retaining social workers, the following four primary themes were highlighted: financial, organisational, personal and socioeconomic.

\section{Theme 1: Financial factors}

This theme explains the importance of funding in order for organisations to deliver social services effectively. Should organisations not be funded adequately, they would be forced to reduce programmes, retrench staff and possibly close down altogether. The following two subthemes, which address a lack of funding and low salaries, highlight the financial factors impacting on the execution of social services.

\section{Subtheme 1.1: Lack of funding}

The participants referred to the lack of funds or resources as an important factor that hampers service delivery, leading to staff resignations and retrenchments. The participants mentioned that organisations have experienced significant cuts in their budgets and have had to limit their services, while some are on the verge of closing down, or have closed down, as a result of a lack of funding. One of the participants spoke about the effects of the lack of funding:

Lack of resources, especially the funds. The money that we get from Social Development is not enough to run the organisation. We have to do fundraising ... and that takes a lot of our time because we cannot focus on one thing only. The issues are mainly with salary, because this place is donor funded and we do not have enough funds.

According to the Department of Social Development Annual Report (2009b), organisations have a key role to play in the delivery of social services. However, they are still expected to protect and promote the development of vulnerable children, although they are faced with several obstacles such as a lack of funding, resources and staff, as well as a lack of support from government. Loffell, Allsopp, Atmore and Monson (2008) state the following as problems faced by the NPO sector: a shortage of social workers; poor recognition of other social service practitioners; a lack of funding; low salaries; and high staff turnover. Strolin et al. (2007) highlight organisational factors that have an influence on high staff turnover such as heavy caseloads, job satisfaction, organisational climate and culture, salaries, benefits, promotional opportunities, and administrative burdens. Many reasons contribute to the high turnover of social workers and these include poor working conditions, poor compensation, lack of resources and support, and increased demands for services.

The participants expressed their frustration at the low level of subsidies received from government, as the services they offer are expensive and wide-ranging. The respondents expressed extreme frustration regarding the Policy on Financial Awards to Service Providers for NPOs and the effect this has on their delivery of services. The participants were also concerned about their inability in the NPO sector to render services because of inadequate remuneration for these services as well as time, cost and resource constraints in terms of fundraising, resulting in services either reverting to the government or collapsing altogether. One participant described the challenges that they face:

I think it is finance; finance is one of the main, main problems that we have because what we have is not enough ... the financial award policy has much effect on the allocation of funds to the Organisation ... there are so many challenges. 
Mismanagement of funding was also highlighted as one of the barriers to effective service delivery. Participants explained that organisations attempt to overcome the problem of inadequate funding by embarking on fundraising on an ongoing basis and by negotiating contacts for financial support from individuals, corporations, foreign donors, trusts and foundations. One of the participants concurred with this assertion:

The biggest drawback is funding and mismanagement of funds ... Government budgets for children's care and protection is extremely small or constrained. We survive by doing fundraising and maybe donations here and there.

The lack, as well as the mismanagement, of funding has exacerbated the layoffs of social workers in organisations. De Sas Kropiwnicki (2010) and Nel et al. (2008) caution that financial cuts within the NPO sector lead to job losses, loss of knowledge and experience, reduced employment opportunities, and the closing down of organisations. The authors further report that organisations need funding to sustain and expand existing services and the remuneration of employees. Funding will also help in the monitoring, evaluation and training of employees thus leading to the retention of social workers. Through fundraising and donations they will be able to generate funds for projects, complete their programmes and pay salaries to employees. The researcher cautions that should organisations not be funded in the near future, they will be forced to cut down on programmes, retrench staff and possibly close down, exacerbating the plight of vulnerable groups and jeopardising the retention of social workers.

\section{Subtheme 1.2: Low salaries}

The participants were concerned about low salaries and the discrepancy in salaries between NPO and government social workers. The excerpt below underscores this concern.

There is clearly not enough social workers to deal with the demands of social services due to low salaries that we get.

The participants stated that salaries need to be equalised in order to retain professionals across the provinces in the private and public sectors. The study has shown that late funding meant that salaries could not be paid on time, communities being serviced went without food, and social work practitioners could not travel to investigate cases, forcing organisations to negotiate costly overdrafts to pay employees' salaries and continue critical service delivery. As a result there is a high turnover, because employees move into the government sector, where workloads are not only lighter but salary packages are also considerably better, or they move outside the social sector where there is less stress, or they immigrate to other countries. The following comment confirms participants' view:

The other problem that we have is that we are underpaid and we work abnormal hours. The government needs to provide equal remunerations of organisation staff to be on the same level as its own staff in order to avoid losing staff members.

The disparities in salaries were identified by Kusluvan (2003) and Taylor (2003), who assert that a lack of fairness in the distribution of salaries causes friction between employees, leading to high staff turnover. The authors further found that the main reasons for a high staff turnover are low salaries and working conditions. De Benitez (2011) and Dunn and Parry-Williams (2008) confirm that organisations responsible for delivering social services are poorly funded and employees are underpaid. Budlender and Proudlock (2011) claim that government subsidies paid to organisations do not cover the full cost or scope of social services. The challenge has become more acute in the wake of the global financial crisis, which has resulted in widespread budget cuts. Among other things, this has resulted in reduced funding for some organisations that provide services on behalf of the Department.

\section{Theme 2: Organisational factors}

This theme emphasises the dilemma faced by organisations in delivering effective social services. The participants highlighted the following three issues, described as subthemes below. 


\section{Subtheme 2.1: Insufficient collaboration between organisations and government}

Findings which emerged from this study indicate a lack of coordination and cooperation between the government and organisations, which contributes to the serious difficulties experienced by organisations. A participant had the following to say on this issue:

Poor collaboration, especially with government, is a major problem. Work allocation is not distributed equally and they have so many restrictions especially on our part.

It was pointed out by most participants that there are generally a limited number of consultations with regard to policy implementation, and that employees need to be trained on how to properly implement these policies, as the problem with vulnerable groups is a complex one that requires a multifaceted approach. The participants insisted that the role of government versus the NPO sector in respect of service delivery needs to be clearly stipulated and defined to ensure cohesion. The participants complained about the difficulties they are faced with when they have to wait for assistance from the Department of Social Development. The participants felt undervalued and ignored by the Department of Social Development, leading to a loss of trust and confidence in management. One participant had the following to say in this regard:

In this particular case, placement was not done because there was no social worker and the Department of Social Development ignores the problem. They know about this since they are the ones that dump the children here.

Pare (2003) claims that the recruitment and retention of employees have shown gaps and shortcomings because of the difficulties organisations face in terms of funding and a shortage of employees. Organisations have a limited ability to refuse government referrals for fear of losing their funding subsidies (Lombard, 2007; Lombard \& Kleijn, 2006). At the same time organisations are faced with the high turnover of employees, as social workers seek to move elsewhere - into the government sector where the workload is not only lighter but salary packages are also considerably better, or to careers in another countries, or outside the social sector (Department of Social Development Annual Report, 2011; Earle, 2008b; Lombard, 2008). Social workers weigh the costs of staying in the NPO sector against the fringe benefits and higher salaries that they can receive should they move into the government sector.

\section{Subtheme 2.2: Heavy workloads}

The participants indicated that there is lack of capacity. While social workers are inundated with foster care grant applications, some resign while others are retrenched, and qualified social workers are absorbed by the Department of Social Development because of the better remuneration provided, thus leaving NPOs trapped in a poorly funded situation. The lack of social workers exacerbates the workload problem, as the remaining employees are called upon to assume the duties of their coworkers. As a result, their performance may also decline due to the low morale, causing more stress and incidences of burnout. The shortage of social workers which exacerbates the lack of service delivery is described by a participant:

There are clearly not enough social workers to deal with the demands of social services. First, there is a scarcity of appropriate skills to provide social services, which impacts significantly on the delivery of prevention and early intervention services.

Lombard (2005) adds that the difficulties faced by social workers that lead to the high staff turnover in the NPO sector include high caseloads, which is made more difficult by the lack of resources, excessive policy changes that lead to more paperwork, discrepancies in salaries between NPOs and government social workers, and the mass departures from the profession to other career possibilities, either in another country or outside the NPO sector. The researcher further highlights that a high percentage of social workers' caseloads entail statutory work and therefore focus on children and families, which results in social workers being charged with unprofessional conduct by the families they service, since they cannot cope with the demands arising from an unmanageable case workload. Giese (2010) and 
Lombard (2005) have shown that a very high percentage of social workers cannot cope with the demands arising from an unmanageably high casework load as a result of dealing with statutory work. Whitaker, Weismiller and Clark (2006) point out that the retention of social workers is an immediate and pressing professional and practical concern. There is a serious shortage of social workers caused by the exodus from the profession at an alarming rate and the resultant classification of social work, and this needs immediate intervention (Calitz, Roux \& Strydom, 2014).

\section{Subtheme 2.3: Lack of job clarification}

The participants maintained that the roles of government versus those of the NPO sector in respect of service delivery need to be clearly stipulated and defined, as they often receive two different and even conflicting sets of instructions from the two different authorities. This causes confusion and shifting of responsibilities among colleagues. One of the participants had the following to say:

You will find that sometimes there is power struggle because our organisation does appoint its own residential social worker but the Social Development at the same time designates its own social worker to work in the same organisation.

The resultant lack of clarity about roles and responsibilities can also have a more pernicious impact on the confidence and competence of those who should be performing these duties (Searle \& Patent, 2013). Despite all the efforts and programmes aimed at addressing the plight of vulnerable groups, the needs of these groups are simply not being met as a result of the lack of sufficient resources such as funding and trained staff, as well as a lack of proper planning and implementation of government policies. In addition, Giese (2010), Patel (2005) and Sanchez (2010) identify the major challenges to social service delivery as the shortage of social service practitioners - in particular social workers, social auxiliary workers and child and youth care workers, community development workers, probation officers, social security personnel, and social care workers. This impacts negatively on the social work aims of enhancing the social functioning and wellbeing of individuals within society through empowerment, and promoting social change and problem solving within human relationships (Van Tonder \& Fourie, 2015).

\section{Theme 3: Personal factors}

In this theme participants articulated the impact on them of emotional exhaustion, low morale, stress and burnout, and how all of these can have a direct and indirect impact on their on-the-job experiences, service quality and potentially service-user experience, particularly when experienced staff leave, and service users are repeatedly exposed to new social workers. The participants emphasised the following concerns, described in the subthemes below.

\section{Subtheme 3.1: Emotional exhaustion}

Because of social work staff shortages, the remaining social workers employed by organisations are forced to take on heavier caseloads. The high social worker turnover causes distress to clients and adversely affects the remaining staff as well as the new, inexperienced social workers. One participant shared the following view:

I am going through emotional breakdown. I am not coping with the workload that does not match my salaries. My family is relying on me for everything ... I cannot even take them out let alone a smaller holiday break. We as social workers fail to meet the needs of the clients ... I think they have lost trust in us.

This participant's outcry is in line with the literature, which indicates that social workers experience stress arising from helping others, which can test their personal coping skills, and induce burnout as a result of not being able to cope with the high demands of the job or reach their personal aspirations (Blom, 2012). For many social workers the ability to manage cases and meet the needs of the families they service, while also meeting the logistical demands of the position, can become overwhelming and stressful. High caseloads, limited time to complete tasks and tight deadlines prevent social workers 
from following up on cases, making it difficult to complete their work at the standard the clients need. This can cause emotional exhaustion and lack of a sense of personal accomplishment among social workers, resulting in burnout. According to Hamama (2012), the nature of the social work profession is mentally and emotionally demanding, frequently leaving personal self-care needs unmet. This vicious circle can also explain the findings of Anderson (2000), who revealed that a significant proportion of social workers have no intention of staying with their respective organisations because of the highly demanding work environment. Regrettably, according to Niven in Betancourt-Perez (2019), protecting social workers' emotional and mental needs is not a high priority in most organisations. For decades the social work profession has failed its workers by not providing them with effective supervision and support to keep them physically and mentally healthy.

\section{Subtheme 3.2: Low morale, stress and burnout}

The participants highlighted problems such as high caseloads, lack of resources, discrepancies in salaries between NPO and government social workers, and departures from the profession as factors leading to low morale, stress and burnout in the remaining number of social workers. The shortages of social service professionals must be addressed urgently and efficiently through enhanced deployment and capacity building. The participants believe that the active use of other social service practitioners such as child and youth care workers, social auxiliary workers and community development workers can help in the delivery of social welfare services in the NPO sector to the children living on and off the streets. The participants had the following concerns to share with regard to this dilemma:

\section{I feel helpless, anxious and stressed at the same time. We tried so many avenues to negotiate with the government bus seems in vain. With this kind of environment one is caught between leaving and staying. If I leave, I will be failing my community and if I stay, I will be failing my family since I cannot meet their needs. To tell you the truth we are not coping with the high cases ... we are worn-out. Cost of living is too high ... we need extra hands ... resources....}

Contributing to the high employee turnover are high caseloads, inefficiency, workplace stress and anxiety, emotional burnout, and even incidents of malpractice, as social work is reduced to the level of crisis management (Earle, 2008a; Lombard, 2008). According to Ray, Davey and Nolan (2011), working effectively with children living on and off the streets requires experience and skill, but there is a lack of resources for employee training which leads to burnout and high employee turnover. Burnout can occur in any occupational group; however, social workers are particularly at risk as a result of working conditions, excessive paperwork, long working hours, little opportunity for personal advancement, and overly bureaucratic structures (Anderson, 2000; Tham \& Meagher, 2009). Burnout may also increase absenteeism, sick leave and turnover rates, thus reducing work quality (Lloyd, King, $\&$ Chenoweth, 2002). Ultimately, low morale, stress and burnout may have a negative impact on clients from vulnerable and marginalised populations that require high-quality and sensitive services. Burnout is believed to be a consequence of prolonged exposure to work stressors, which leads to feelings of cynicism because of emotional exhaustion (Lizano \& Barak, 2015). On an organisational level, factors such as high caseloads, lack of control over policies and procedures, inadequate supervisory support, low compensation, staff shortages and lack of training can all lead to professional burnout (Calitz et al., 2014). Organisations that experience stressors become collectively traumatised, staff exhibit high levels of burnout, low levels of compassion, little or no work satisfaction, and they experience secondary trauma. When organisations and individuals become traumatised by the work they do, the services delivered to their community are bound to suffer (Handran, 2013).

\section{Theme 4: Socioeconomic factors}

The NPOs are poised to cut back their services or close their doors, while retrenchments are already taking place in alarming numbers as a result of socioeconomic factors. From the subthemes set out below it seems that the government has thus far been unsuccessful in its attempts to resolve the problems facing vulnerable groups and has to date failed to come up with solutions with regard to funding the NPOs. 


\section{Subtheme 4.1: Retrenchment of social workers}

The findings indicated that NPOs are forced to cut back their services or close their doors, while retrenchments are already taking place in alarming numbers as a result of a lack of funding and other resources. The participants referred to the scarcity of appropriate human resources as the main factor preventing them from delivering regular, quality social welfare services, leading to the high turnover of staff. One participant had the following to say:

The government is failing the organisations ... just to think that we are doing the bulk of their work...There is a possibility of some of us being retrenched soon ... it has happened to colleagues in other organisations. There is no funding ... no sustainability of the organisations. People are being laid off ... it is so sad really.

NPOs are on the brink of closing down and retrenching their staff because of the lack of funding, while some are struggling to operate with only a few employees. The participants mentioned delays in funding from the Ithuba National Lottery as one of the factors that exacerbate insufficient social welfare delivery to vulnerable groups. Tracey and Hinkin (2008) and Nel et al. (2008) state that high staff turnover leads to new personnel recruitment, incurring additional administrative, selection, induction and training costs, to say nothing of the loss of knowledge and experience; this results in low morale among the remaining employees and delays in service delivery.

\section{Subtheme 4.2: Closing down of organisations}

The participants mentioned that NPOs have experienced significant cuts in their budgets and have had to limit their services, while some are on the verge of closing down or have closed down due to the lack of funding. This affects the future of employees in that they either lose their jobs or feel compelled to resign. A participant had the following to share:

So far we have hundreds of organisations that have closed down ... some in the process due to lack of resources. We are not an exception to the rule ... if there is such. Someone is siting up there and not caring about the wellbeing of the vulnerable people. There is real poverty out there at the same time unfortunately organisations are closing down.

This sentiment is supported by Solomons (2012), who asserts that funding from international sources seems to be dwindling. No budgets are provided for NPOs. The author cautions that should organisations not be funded adequately, they will be faced with closure. Streak, Dawes, Ewing, Levine, Rama and Alexander (2008) point out that NPOs have been negatively affected - to say the least - by government not prioritising the allocation of funds to NPOs for the provision and/or continuation of social welfare services. According to the authors mentioned above, a financial crisis currently exists as a result of years of underfunding, diminishing funds to the increasing number of organisations, and the growing demand for services. Many organisations are struggling to deliver services in their domain, let alone expand service delivery to new areas or build capacity in previously disadvantaged organisations, and are thus forced to close. According to Patel and Hochfeld (2008), Ray et al (2011) and Loffel (2012), there is still much to be done to transform welfare services and to increase efforts to retain social workers in South Africa. It seems government has thus far been unable to resolve the problem of staff turnover and has failed to prescribe possible solutions or provide sufficient funding to NPOs.

\section{DISCUSSION OF THE FINDINGS}

From the abovementioned findings, it seems the problems highlighted are not new. Social worker turnover will always be a problem, sometimes to a lesser extent, but social worker retention can never reach a satisfactory level unless prevention plans are put in place by the government. This study was undertaken to explore and describe the dilemmas faced by organisations in retaining social workers in Pretoria. The study reports that organisations are facing significant challenges in relation to the high turnover of social workers, which is exacerbated by financial and organisational factors. The high turnover creates significant costs in terms of staff replacement, recruitment, selection, low morale, added pressure on remaining staff, and a consequent poor quality of service. This high turnover is 
further exacerbated by red tape, bureaucracy, poor quality of the partnership between the Department of Social Development and organisations, as well as the lack of funding. Organisations are faced with substantial financial constraints, which in many instances forces them to close down, while most social workers are on the brink of losing their valuable jobs; at the same time, the vulnerable, marginalised children on the ground are left facing even greater disadvantages. The truth of the matter is that the rights of social workers are being violated. There is an acknowledgement that there needs to be more systematic engagement between government and organisations, and that the two sectors have complementary roles to play in the process of retaining social workers.

As a result of their highly demanding and challenging roles and responsibilities, social workers are prone to work-related burnout. Serving vulnerable children and families and providing them with support and empathy are at the core of social workers' professional responsibility. However, social workers are not given the support they need to function in their highly stressful occupations. Furthermore, the study found that heavy workloads compel social workers to choose other careers that they perceive as requiring less input of time and energy. There is too much work to accomplish in the time available with limited resources, which in turn leads to burnout. Emotional exhaustion is a significant predictor of voluntary turnover, since social workers function to provide services to a disenfranchised, vulnerable population; however, they are also at risk of becoming vulnerable through work-related stress and burnout.

\section{CONCLUSIONS AND RECOMMENDATIONS}

Social workers have an important role in responding to the needs of vulnerable groups. But because of the demanding nature of social work, social workers are frequently affected by a number of factors which, if not addressed, often lead to high staff turnover. From this study it is clear that financial, organisational, personal and socioeconomic factors create the challenges faced by organisations in retaining social workers. This trend will continue unless there is cooperation between organisations and the government, and prevention measures are put in place. Nonetheless, there are NPOs that are surviving despite the challenge of funding, while some are subjected to many challenges, from retrenching workers to closing their doors to the needy. The existing programmes have been beset by many funding problems, forcing some children back on to the streets, NPOs to close down or retrench workers, and even face litigation in an attempt to fight for funding from government. Some NPOs cannot function as a result of cuts in funding. There is acknowledgement that there needs to be more systematic engagement between government and NPOs, and that the two sectors have complementary roles to play in the process of retaining social workers to render the necessary services.

The study highlights the following recommendations in order to retain social workers: recommendations for practice are that NPOs and the Department of Social Development need to find new innovative funding resources and a variety of strategies to cope with the economic uncertainties in order to allow organisations' sustainability; the salaries for social welfare practitioners need to be improved and be equal across all spectrums to avoid movement of social workers from NPOs to government departments or abroad; salary and wage policies need to be evaluated by policy makers in order to retain social workers, and there should be continuous monitoring; salaries for social welfare practitioners need to be improved and should be equal across all spectrums to avoid the movement of social workers from NPOs to government departments; the shortage of social workers and the nature of work allocation should be taken into account.

Lack of and poor funding of the programmes disadvantage NPOs in that they fail to deliver the social welfare services as expected. More focus should be on prevention and early intervention services based on coordination with the NPO sectors and government departments. There is therefore a definite need for prevention and early intervention services to receive more attention and be prioritised, while more funding should be allocated to prevention and early intervention services. NPOs and the DSD need to find new, innovative funding resources and a variety of strategies to cope with economic uncertainties to ensure sustainability. 
The DSD and NPOs should clarify their memorandum of understanding or service-level agreements to enhance collaboration in order to clarify the roles of government and NPOs. There should be role clarification in order to alleviate the power struggle between organisations.

NPOs struggle with few resources and are detrimentally affected by budget cuts. The cost of staff turnover has become untenable and NPOs have to devise retention strategies to reduce the rate of social worker turnover. Recommendations with regard to the policy for financial awards to service providers need to be reviewed in order to meet the NPO sector's concerns. The Financial Policy Award needs to accommodate all NPOs irrespective of the kind of social welfare services rendered. The lack of collaboration between the government and NPOs results in vulnerable groups not being served effectively, thus exacerbating the phenomenon because of the policies that do not cater for them. There should be collaboration between policy makers from government and NPOs in order to develop realistic and practical strategies.

A few limitations of the study were identified. The qualitative nature of the study, the small sample size, and the fact that the study was confined to a specific setting/area meant that the research findings cannot be generalised to settings elsewhere in the country, as this study focused only on selected social workers employed at NPOs in Pretoria. To address these limitations, further research is recommended. A cross-national study should be undertaken on job losses experienced in the NPO sector as a result of the lack of resources and funding. Data should be gathered on the scale of job losses in the NPO sector, how many NPOs have closed down or had to downsize services. There is also a need for research to be conducted to fill the information gap on the effects of programmes rendered to vulnerable groups, and to focus on the effectiveness of service delivery.

From the findings it can be concluded that the strategy employed by government to retain social workers and to sustain organisations has thus far failed and needs to be revisited to avoid the closing down of organisations, reducing services, retrenching staff, and putting vulnerable children and families at risk. The findings clearly highlight that the negative effects of social worker turnover are serious enough to warrant concern and intervention.

\section{REFERENCES}

ABBASI, S.M. \& HOLLMAN, K.W. 2000. Turnover: The real bottom line. Public Personnel Management, 29(3):333-342. Available: doi:1177/00910260000 2900303

AMSTRONG, M. 2006. Human resource management ( $9^{\text {th }}$ ed). London: Kogan Page.

ANDERSON, D.G. 2000. Coping strategies and burnout among veteran child protection workers. Child Abuse and Neglect, 24(6):839-848. Available: doi:10.1016/S0145-2134 (00)00143-5

BARBERTON, C. 2006. The cost of the Children's Bill: Estimates of the cost to government of the services envisaged by the Comprehensive Children's Bill for the period 2005 to 2010. Pretoria: Cornerstone Economic Research.

BETANCOURT-PEREZ, V. 2019. Child welfare social workers' perspective on factors that influence longevity. California State University, San Bernardino. (Masters thesis)

BLOM, V. 2012. Contingent self-esteem, stressors and burnout in working women and men. Work, 43:123-131.

BUDLENDER, D. \& PROUDLOCK, P. 2011. Funding the Children's Act: Assessing the adequacy of the 2011/12 budgets of the provincial departments of social development. Cape Town: Children's Institute, University of Cape Town.

BUDLENDER, D., WILLIAMS, L., SAAL, Q., SINEKE, T. \& PROUDLOCK, P. 2011. Funding of Children's Act - related services. Johannesburg: Community Agency for Social Enquiry. 
BURNS, N. \& GROVE, S.K. 2010. Understanding nursing research: Building an evidence-based practice $\left(4^{\text {th }}\right.$ ed). New York: Elsevier Health Sciences.

CALITZ, T., ROUX, A. \& STRYDOM, H. 2014. Factors that affect social workers' job satisfaction, stress and burnout. Social Work/Maatskaplike Werk, 2014:50(2). Available: doi:10.15270/50-2-2-393

CAUVAIN, S. 2010. Social workers do not feel valued by either their employer or the general public. Social Work Now, November, 20.

CONSTITUTION OF THE REPUBLIC OF SOUTH AFRICA. 1996. Act 108 of 1996. Pretoria: Government Printers.

CRESWELL, J.W. \& PLANO CLARK, V.L. 2011. Designing and conducting mixed methods research (2nd ed). Thousand Oaks: Sage Publications.

CRESWELL, J.W. 2014. Research design: Qualitative, quantitative, and mixed methods approaches $\left(4^{\text {th }}\right.$ ed). Los Angeles: Sage Publications.

CRESWELL, J.W. 2009. Research design: Qualitative, quantitative and mixed methods approaches $\left(3^{\text {rd }}\right.$ ed). London: Sage Publications.

CURTIS, L., MORIARTY, J. \& NETTEN, A. 2009. The expected working life of a social worker. British Journal of Social Work, 40(5):1628-1643. Available: doi:10.1093/ bjsw/ bcp039

DE BENITEZ, S.T. 2011. State of the world's street children: Research. London: Consortium for Street Children.

DE SAS KROPIWNICKI, Z. 2010. Identification and assessment of early intervention and prevention programmes in South Africa: Desk review. Draft. DoSD \& UNICEF.

DEPARTMENT OF SOCIAL DEVELOPMENT. 2009a. Retention and Recruitment Strategy for Social Workers. Pretoria: Government Printers.

DEPARTMENT OF SOCIAL DEVELOPMENT. 2009b. Developing Good Governance Practices within the South African NPO Sector. Pretoria: Government Printers.

DEPARTMENT OF SOCIAL DEVELOPMENT. 2010. National Policy Framework and Strategy. Pretoria: Government Printers.

DEPARTMENT OF SOCIAL DEVELOPMENT. 2011. The State of NPO Registration South Africa. A Report from the National NPO Database. Pretoria: Government Printers.

DU PLOOY, J. \& ROODT, G. 2010. Work engagement, burnout and related constructs as predictors of turnover intentions. South African Journal of Industrial Psychology, 36(1):1-13. Available: doi:10.4102/sajip.v36i1.910

DUNN, A. \& PARRY-WILLIAMS, J. 2008. Alternative care for children in Southern Africa: Progress, challenges and future directions, ESARO Working Paper. Nairobi: UNICEF.

EARLE, N. 2008a. Social work in social change: The profession and education of social workers in South Africa. Pretoria: HRSC Press.

EARLE, N. 2008b. Social work as a scarce and critical profession: Scarce and critical skills research project. Human Sciences Research Council (HSRC), Development Policy Research Unit (DPRU) and Sociology of Work Unit Research Consortium. Research commissioned by the Department of Labour, South Africa.

ELLETT, A.J. 2009. Intentions to remain employed in child: The role of human caring, selfefficacy beliefs, and professional organizational culture. Child and Youth Services Review, 31(1):78-88. Available: doi:10.1016/j.childyouth.2008.07.002 
GIESE, S. 2010. Identification and assessment of early intervention and prevention programmes in South Africa: Rapid review of legal and policy documents pertaining to prevention and early intervention services in South Africa. Cape Town: DoSD \& UNICEF.

GIESE, S. 2008. Setting the scene for social services: The gap between service need and delivery. In: PROUDLOCK, P., DUTSCHKE, M., JAMIESON, L., MONSON, J. \& SMITH, C. (eds). South African Child Gauge (17-22). Cape Town: Children's Institute, University of Cape Town.

HAMAMA, L. 2012. Differences between children's social workers and adults' social workers on sense of burnout, work conditions and organizational social support. British Journal of Social Work, 42:1333-1353. Available: doi: 10.1093/bjsw/ber135

HANDRAN, J. 2013. Trauma informed organizational culture: The prevention, reduction, and treatment of compassion fatigue. Colorado State University at Fort Collins. Ann Arbor, MI: ProQuest (Doctoral thesis).

JACOBS, E. 2012. Society for Human Resource Management. SHRM 2012-2013. Human Capital Benchmarking Report. Virginia: SHRM.

KREFTING, L. 1991. Rigor in qualitative research: The assessment of trustworthiness. American Journal of Occupational Therapy, 45:214-222. Available: doi:10.5014/ajot.45.3.214

KUSLUVAN, S. 2003. Multinational enterprises in tourism: A case study of Turkey. Glasgow, Strathclyde University (D.Phil. Thesis)

LANDSMAN, M.J. 2001. Commitment in public child welfare. Social Services Review, 75(3):386-419. Available: doi:10.1086/322857

LASHLEY, C. 2000. Hospitality retail management: A unit manager's handbook. Oxford: Butterworth-Heinemann.

LITTELL, J. \& SHLONSKY, A. 2010. Towards evidence informed policy and practice in child welfare. Research on Social Work Practice, 206: 723-725. Available: doi:10.1177/1049 731509347886

LIZANO E.L., BARAK M.M. 2015. Job burnout and affective wellbeing: A longitudinal study of burnout and job satisfaction among public child welfare workers. Child Youth Service Reviews, 55(2015):18-28.

LOFFEL, J. 2012. Short-change for a tall order of social development. Mail \& Guardian, 22- 28:36.

LOFFEL, J., ALLSOPP, M., ATMORE, E. \& MONSON, J. 2008. Human resources needed to give effect to children's right to social services. In: PROUDLOCK, P., DUTSCHKE, M., JAMIESON, L., MONSON, J. \& SMITH, C. (eds). South African Child Gauge, 2007/2008, (48-54). Cape Town: Children's Institute, University of Cape Town.

LOMBARD, A. \& KLEIJN, W.C. 2006. Statutory social services: An integral part of developmental social service delivery. Social Work/Maatskaplike Werk, 42(3):4. Available: doi:10.15270/42-3-295

LOMBARD, A. 2005. Impact of social services on human, social and economic development and the promotion of human rights in South Africa. Social Work/Maatskaplike Werk, 41(3):209-228.

LOMBARD, A. 2007. The impact of social welfare policies on social development in South Africa: An NGO perspective. Social Work/Maatskaplike Werk, 43(4): 295-316. Available: doi:10.15270/43-4-260 
LOMBARD, A. 2008. The impact of social transformation on the non-government sector and the social work profession. International Journal of Social Work, 17(2):124-131. Available: doi:10.1111/j.1468-2397.2007.00550.x

LLOYD, C., KING, R., CHENOWETH, L. 2002. Social work, stress, and burnout. Journal of Mental Health, 11(3): 255-265.

MABETOA, M. 2018. Social Development Committee Meeting. 31 October 2018.

MARTIN, P. 2010. Government-funded programmes and services for vulnerable children in South Africa. Cape Town: HSRC Press.

NEL, P., WERNER, A., HAASBROEK, G., POISAT, P., SONO, T. \& SCHULTZ, H. 2008. Human resource management $\left(7^{\text {th }}\right.$ ed). Cape Town: Oxford University Press.

NATIONAL ASSOCIATION OF SOCIAL WORKERS. 2017. Ethical principles. Available: https://www.socialworkers.org/LinkClick.aspx? fileticket=ms_ ArtLqzeI\%3D\&portalid=0. [Accessed: 20/04/2018].

PARE, M. 2003. Why have all the children living on and off the streets disappeared? The role of international human rights law in protecting vulnerable groups. International Journal of Children's Rights, 11(1):1-32. Available: doi:10.1163/092755603322384001

PATEL, L. \& HOCHFELD, T. 2012. Developmental social work in South Africa: Translating policy into practice. International Social Work, 56(5):690-704. Available: doi:10.1177/ 0020872812444481

PATEL, L. \& HOCHFELD, T. 2008. Indicators, barriers and strategies to accelerate the pace of change to developmental welfare in South Africa. The Social Work PractitionerResearcher/Die Maatskaplikewerk Navorser-Praktisyn, 20(2):192-211.

PATEL, L. 2005. Social welfare and social development in South Africa. Cape Town: Oxford University Press.

PATEL, L. 2010. Pointers for future research on gender and care in voluntary organisations in Southern Africa. The Social Work Practitioner-Researcher entitled "Towards an African social development research strategy", special issue, 39-53.

RAY, P., DAVEY, C. \& NOLAN, P. 2011. Still on the street - still short of rights: Analysis of policy and programmes related to street involved children. Text. Plan and Consortium for Street Children. British Library Cataloguing in Public Data.

ROBINS, S.P. \& JUDGE, T.A. 2011. Organisational behavior $\left(14^{\text {th }}\right.$ ed $)$. London: Pearson Education.

RUBIN, A. \& BABBIE, E. 2013. Research methods for social work $\left(8^{\text {th }}\right.$ ed $)$. Brooks/Cole Cengage Learning.

SANCHEZ, D. 2010. Civil society responses to homelessness. Development Southern Africa, 27(1):101-110. Available: doi:10.1080/03768350903519382

SCHUDRICH, W.Z., AUERBACH, C., LIAO, A., LAWRENCE, C., FERNANDERS, G., MCGOWAN, B.G. \& CLAIBORNE, N. 2013. Intention to leave in social workers and educators employed in voluntary child welfare agencies. Children and Youth Services Review, 34(5):657-663. Available: doi:10.1016/j.childyouth.2013.01.010

SEARLE, R.H. \& PATENT, V. 2013. Recruitment, retention and role slumping in child protection: the evaluation of in-service training initiatives. The British Journal of Social Work, 43 (6): 1111-1129. 
SKHOSANA, R.M. 2013. Social welfare services rendered to street children in Pretoria: Service providers' perspective. Pretoria: University of the South Africa. (Masters dissertation)

SOLOMONS, M. 2012. Focus Programme. SABC 2. 20.10.2012.

STROLIN, J., MCCARTHEY, M. \& CARINGI, J. 2007. Causes and effects of child workforce turnover: current state of knowledge and future directions. [Online] Available:

http://ocfs.ny.gov/ohrd/swec/pubs/Causes\%20and\%20Effects\%20of\%20Child\%20\%20

Workforce\%20Turnover.pdf. [Accessed 09/09/2014].

STREAK, J. \& POGGENPOEL, S. 2005. Towards social services for all vulnerable children in South Africa. Idasa Budget Information Service Occasional Paper. Cape Town: Idasa.

STREAK, J., DAWES, A., EWING, D., LEVINE, S., RAMA, S. \& ALEXANDER, L. 2008. Children working in the commercial and subsistence agriculture in South Africa: A child labour-related rapid assessment study. Cape Town: HSRC Press.

TAYLOR, G. 2003. Talent management strategies. People Dynamics, 21(7):5-7.

THAM, P. \& MEAGHER, G. 2009. Working in human services: How do experiences and working conditions in child welfare social work compare? The British Journal of Social Work, 39(5):807-27.

TRACEY, B. \& HINKIN, T. 2008. Contextual factors and cost profiles associated with employee turnover. Cornell Hospitality Quarterly, 49(1):12-27. Available: http://dx.doi. org/10.1177/0010880407310191

VAN TONDER, D. \& FOURIE, E. 2015. The effect of job demands and a lack of job resources on South African educators' mental and physical resources. Journal of Social Sciences, 42(1):65-77. Available: https://doi .org/10 .1080/09718923.2015.11893395

VERMEULEN, A. 2008. Understanding the work experiences, coping strategies and organizational retention of social workers in Gauteng in-patient substance abuse treatment clinics. Johannesburg: University of the Witwatersrand. (MA [SW] Dissertation)

WARD, C.L. \& SEAGER, J.R. 2010. South African street children: A survey and recommendations for services. Development Southern Africa, 27(1):85-100. Available: doi: $10.1080 / 03768350905319374$

WHITAKER, T., WEISMILLER, T. \& CLARK, E. 2006. Assuring the sufficiency of a frontline workforce: a national study of licensed social workers: Executive summary. Washington, D.C.: National Association of Social Workers. 